\title{
A Block in Glycine Cleavage Reaction as a Common Mechanism in Ketotic and Nonketotic Hyperglycinemia
}

\author{
KEIYA TADA ${ }^{(14)}$ \\ Department of Pediatrics, Osaka City University Medical School, Japan \\ LUCIEN M. CORBEEL, ROGER EECKELS, AND EPHREM EGGERMONT \\ Department of Pediatrics, University of Leuven, Belgium
}

\section{Extract}

Our previous study demonstrated a block in glycine cleavage reaction in the liver from two patients with hyperglycinemia of the nonketotic type. The present study extended this work to two other patients with nonketotic hyperglycinemia and a patient with ketotic hyperglycinemia. The liver specimens obtained from these patients by autopsy or biopsy were studied for the activities of glycine cleavage reaction and of serine hydroxymethylase.

A low activity of glycine cleavage reaction was found in all three patients with nonketotic or ketotic hyperglycinemia, whereas the activity of serine hydroxymethylase remained within normal limits.

\section{Speculation}

The present study suggests that a block in the glycine cleavage reaction, either primarily or secondarily, plays an important role in glycine accumulation in both types of hyperglycinemias.

Hyperglycinemia represents a group of disorders characterized by elevated concentrations of glycine in body fluids. The disorder is now divided into two forms, the ketotic and the nonketotic. In nonketotic hyperglycinemia, a defect of the glycine cleavage enzyme in the liver was found to be responsible for the accumulation of glycin $(5,12,13)$. On the other hand, it has been demonstrated that ketotic hyperglycinemia is virtually due to propionic acidemia, methylmalonic acidemia, isovaleric acidemia $(2,6,11)$. However, the mechanisms of abnormal accumulation of glycine remain unsolved in ketotic hyperglycinemia.

Recently we had the opportunity to investigate the activity of the glycine cleavage enzyme in the liver obtained from two patients with nonketotic hyperglycinemia and one patient with ketotic hyperglycinemia.

\section{MATERIALS AND METHODS}

Case $M F$, a girl (nonketotic hyperglycinemia), was born after a full term pregnancy and spontaneous delivery. Her neonatal history was uneventful. After the first attack at 3 months of age, the patient had occasional episodes of general convulsions. Mental retardation became evident gradually. She showed constantly elevated levels of glycine (6.0-10.0 $\mathrm{mg} / 100 \mathrm{ml}$ ) and normal levels of propionic acid, methylmalonic acid, and isovaleric acid in the blood. No ketoacidosis was present. The liver specimen was biopsied at the age of 5 years.

Case $L K$, a girl (nonketotic hyperglycinemia), was born after a full term pregnancy and spontaneous delivery. The girl was normal up to the 4th day of life, when she was found to be comatose and hypotonic. Laboratory examinations revealed a high level of serum glycine $(17 \mathrm{mg} / 100 \mathrm{ml})$ and normal levels of propionic acid, methylmalonic acid, and isovaleric acid in blood.

No ketoacidosis was present. The patient died on the 5 th day of life and the liver specimen was obtained immediately after death.

Case $V A$, a girl (ketotic hyperglycinemia), was born after a full term pregnancy and spontaneous delivery. She began to vomit in the 1st week of life. The girl was hospitalized at the age of 2.5 months, when she was comatose, dehydrated, and grossly underweight. Laboratory examinations showed a high level of serum glycine $(9.0 \mathrm{mg} / 100 \mathrm{ml})$ and a remarkable elevation of propionic acid $(7.6 \mathrm{mg} / 100 \mathrm{ml})$ and methylmalonic acid $(12.1 \mathrm{mg} / 100 \mathrm{ml})$. Marked acidosis was present, indicating blood $\mathrm{Ph} 7.06, \mathrm{HCO}_{3} 9.5 \mathrm{mEq} /$ liter, and acetonuria. She died $48 \mathrm{hr}$ after admission in spite of intravenous fluid therapy and peritoneal dialysis. The liver specimen was obtained immediately after death.

Case OR (trisomy 13) died at 4 months of postnatal age; the liver specimen was obtained immediately after death.

Case $M M$ (congenital heart disease) died at 3 days of postnatal age; the liver specimen was obtained immediately after death.

Case $H Y$ (pneumonia) died at 6 days of postnatal age; the liver specimen was obtained immediately after death.

The liver specimens from the latter three patients served as controls. These control specimens were comparable with those from hyperglycinemic patients in respect to age and time of storage. The liver specimens obtained from the patients were deep frozen $\left(-80^{\circ}\right)$ until analysis. Using the liver homogenate, glycine cleavage reaction was estimated by the method described previously (12), with addition of tetrahydrofolate (1 $\mu \mathrm{mol})$, pyridoxal phosphate $(1.5 \mu \mathrm{mol})$, and NAD $(1 \mu \mathrm{mol})$ into the assay system. The activity of serine hydroxymethylase was determined by the method of Bertino et al. (4). Glycine concentration of the liver homogenate was determined by the method of Alexander et al. (1). 
Table 1. Assay of glycine cleavage reaction ${ }^{1}$

\begin{tabular}{|c|c|c|c|c|c|}
\hline \multirow[b]{2}{*}{ Subjects } & \multicolumn{2}{|c|}{${ }^{14} \mathrm{CO}_{2}$ formation } & \multicolumn{3}{|c|}{ Incorporation of ${ }^{14} \mathrm{C}$ into serine } \\
\hline & $\begin{array}{c}\text { From } \\
\left(1-^{14} \mathrm{C}\right) \text { glycine, } \\
\mathrm{cpm} / 10 \mathrm{mg} \text { protein }\end{array}$ & $\begin{array}{c}\text { From } \\
\left(2-^{14} \mathrm{C}\right) \text { glycine } \\
\mathrm{cpm} / 10 \mathrm{mg} \text { protein }\end{array}$ & $\begin{array}{c}\text { From } \\
\left(1-^{14} \mathrm{C}\right) \text { glycine } \\
\mathrm{cpm} / 10 \mathrm{mg} \text { protein }\end{array}$ & $\begin{array}{c}\text { From } \\
\left(2-^{14} \mathrm{C}\right) \text { glycine, } \\
\mathrm{cpm} / 10 \mathrm{mg} \text { protein }\end{array}$ & $\begin{array}{l}\text { Ratio of } \\
\text { incorporation } \\
\left(2-^{14} \mathrm{C}\right) \text { glycine/ } \\
\left(1-{ }^{14} \mathrm{C}\right) \text { glycine }\end{array}$ \\
\hline \multicolumn{6}{|l|}{ Control } \\
\hline Case OR & 3,668 & 883 & 4,470 & 7,739 & 1.73 \\
\hline Case $M M$ & 2,886 & 858 & 2,580 & 4,160 & 1.67 \\
\hline Case $H Y$ & 3,320 & 751 & 2,617 & 5,430 & 2.07 \\
\hline \multicolumn{6}{|l|}{ Hyperglycinemia } \\
\hline$M F$ (nonketotic) & 548 & 615 & 782 & 855 & 1.09 \\
\hline$L K$ (nonketotic) & 476 & 423 & 649 & 795 & 1.22 \\
\hline$V A$ (ketotic) & 728 & 874 & 818 & 1,014 & 1.24 \\
\hline
\end{tabular}

${ }^{1}$ Reaction mixtures contained, in a final volume of $2 \mathrm{ml}$ : $10 \mu \mathrm{mol}\left({ }^{14} \mathrm{C}\right)$ glycine $(0.05 \mathrm{mCi} / \mathrm{mmol}), 190 \mu \mathrm{mol} \mathrm{KCl}, 95 \mu \mathrm{mol}$ potassium phosphate buffer (Ph 7.4), $1 \mu \mathrm{mol}$ tetrahydrofolate, $1.5 \mu$ moles pyridoxal phosphate, $1 \mu \mathrm{mol} \mathrm{NAD}$, and liver homogenate containing $10 \mathrm{mg}$ protein. Reactions were carried out for 1 hr at $37^{\circ}$.

\section{RESULTS}

Data on glycine cleavage reaction and serine hydroxymethylase are shown in Tables 1 and 2 .

It was found that ${ }^{14} \mathrm{CO}_{2}$ formation from $\left(1-{ }^{14} \mathrm{C}\right)$ glycine was distinctly low not only in the livers from the patients with nonketotic hyperglycinemia, but also in the liver from one patient with ketotic hyperglycinemia (methylmalonic acidemia), as compared with that in livers from comparable control subjects. The incorporation of ${ }^{14} \mathrm{C}$ from $\left(1{ }^{14} \mathrm{C}\right)$ glycine and $\left(2-{ }^{14} \mathrm{C}\right)$ glycine into serine was about equal in the livers of the patients, whereas, in control livers, the amounts of $\left({ }^{14} \mathrm{C}\right)$ serine from $\left(2-{ }^{14} \mathrm{C}\right)$ glycine were nearly twice the amounts formed with $\left(1-{ }^{14} \mathrm{C}\right)$ glycine.

These findings indicate a block of the glycine cleavage reaction in the patient's livers. There was no significant difference of the activity of serine hydroxymethylase between the livers of the patients and those of the control subjects.

Table 3 shows that glycine concentration was higher in hyperglycinemic livers than in control livers. These results indicate that a dilution by endogenous glycine is insignificant in the present experiment with $\left({ }^{14} \mathrm{C}\right)$ glycine, inasmuch as excess glycine $(10 \mu \mathrm{mol})$ is added as substrate to the assay system (Table 1).

\section{DISCUSSION}

Glycine cleavage reaction consisting in oxidative cleavage of glycine into methylene tetrahydrofolate (THF), $\mathrm{CO}_{2}$, and $\mathrm{NH}_{3}$ has been extensively studied by Kikuchi et al. $(7-10)$ in rat liver. In in vitro systems, the glycine cleavage reaction is usually accompanied by the concomitant synthesis of serine, as can be explained by the following sequences of reactions.

Table 2. Serine hydroxymethylase activity in liver

\begin{tabular}{cc}
\hline Subjects & $\begin{array}{c}\text { Serine hydroxymethylase, } \\
\mu \mathrm{mol} / \mathrm{mg} \text { protein } / \mathrm{hr}\end{array}$ \\
\hline Control & \\
$O R$ & 0.83 \\
$M M$ & 1.09 \\
$H Y$ & 0.66 \\
Hyperglycinemia & \\
$L K$ (nonketotic) & 0.72 \\
$V A$ (ketotic) & 0.65 \\
\hline
\end{tabular}

Table 3. Glycine concentration in liver

\begin{tabular}{cc}
\hline Subjects & $\begin{array}{c}\text { Glycine concentration in liver, } \\
\mu \mathrm{mol} / 10 \mathrm{mg} \text { protein }\end{array}$ \\
\hline Hypergly cinemia & \\
Case $M F$ & 0.68 \\
Case $L K$ & 0.93 \\
Case $V A$ & 0.77 \\
Control & \\
Case $O R$ & 0.14 \\
Case $M M$ & 0.37 \\
Case $H Y$ & 0.26 \\
\hline
\end{tabular}

Glycine $+\mathrm{THF} \rightarrow$ methylene- $\mathrm{THF}+\mathrm{CO}_{2}+\mathrm{NH}_{3}$ (glycine cleavage reaction) $(I)$

Methylene-THF + glycine $\rightarrow$ serine + THF

(serine hydroxymethylase) (2)

Therefore, in the newly synthesized serine one carbon, the carboxyl carbon, originates from the first carbon of glycine and the two others, carbon 2 and 3 of serine, from the second carbon of glycine.

The data mentioned above clearly indicate a block of the glycine cleavage reaction in the liver of hyperglycinemia. Ando et al. (3) studied the in vivo conversion of intravenously injected $\left(1-{ }^{14} \mathrm{C}\right)$ glycine to respiratory $\mathrm{CO}_{2}$ in three patients with nonketotic hyperglycinemia and three patients with propionic acidemia (ketotic hyperglycinemia).

They found that all patients of both nonketotic and ketotic type revealed an extremely low conversion of $\left(1-{ }^{14} \mathrm{C}\right)$ glycine to $\mathrm{CO}_{2}$ as compared with that in control subjects even when a hyperglycinemia state was produced by continuous infusion of nonisotopic glycine to these control subjects. These findings are consistent with a block in glycine cleavage reaction in both types of hyperglycinemia.

Studies of leucocytes and fibroblasts have proven without doubt that the genetic lesion is a defect of propionyl-CoA carboxylase in propionic acidemia and a defect of methylmalonyl-CoA mutase in methylmalonic acidemia. It is, therefore, reasonable to presume that a block in glycine cleavage reaction observed in the liver of the patient with methylmalonic acidemia is a secondary metabolic disturbance. However, the problem of why glycine cleavage reaction is disturbed in methylmalonic acidemia remains unsolved. In nonketotic hyperglycinemia, a defect of the enzyme catalyzing glycine cleavage reaction is probably primary lesion. 
The present studies suggest that a block in glycine cleavage reaction, either primarily or secondarily, play an important role on glycine accumulation in both types of hyperglycinemia.

\section{SUMMARY}

The liver specimens obtained from two patients with hyperglycinemia of nonketotic type and a patient with hyperglycinemia of the ketotic type were studied for the activities of glycine cleavage reaction and of serine hydroxymethylase.

A low activity for the glycine cleavage reaction was found in all three hyperglycinemic patients, whereas the activity of serine hydroxymethylase was within normal limits. These findings suggest that a block in glycine cleavage reaction may be a common mechanism for glycine accumulation in both types of hyperglycinemia.

\section{REFERENCES AND NOTES}

1. Alexander, B., Landwehr, G., and Seligman, A. M.: A specific micromethod for the colorimetric determination of glycine in blood and urine. J. Biol. Chem., 160: 51 (1945)

2. Ando, T., Klingberg, W. G., Ward, A. N., Rasmussen, K., and Nyhan, W. L.: Isovaleric acidemia presenting with altered metabolism of glycine. Pediat. Res., 5: 478 (1971).

3. Ando, T., Nyhan, W. L., Connor, J. D., Rasmussen, K., Dommell, G., Barnes, N., Cottom, D., and Hull, D.: The oxidation of glycine and propionic acid in propionic acidemia with ketotic hyperglycinemia. Pediat. Res., 6: $576(1972)$.

4. Bertino, J. R., Simons, B., and Donotive, D. M.: Purification and properties of the formate activating enzyme from erythrocytes. J. Biol. Chem., 237: 1314 (1962).

Copyright $\odot 1974$ International Pediatric Foundation, Inc.
5. De Groot, G. J., Troelstra, J. A., and Hommes, F. A.: Non-ketotic hyperglycinemia: An in vitro study of the glycine-serine conversion in liver of three patients and the effect of dietary methionine. Pediat. Res., 4: 238 (1970).

6. Hsia, Y. E., Scully, K. J., and Rosenberg, L. E. Defective propionate carboxylation on ketotic hyperglycinemia. Lancet, $i$ : 757 (1969).

7. Kikuchi, G.: The glycine cleavage system: Composition, reaction, and physiological significance. Mol. Cell Biochem., 1: 169 (1973).

8. Motokawa, Y., and Kikuchi, G.: Glycine metabolism by rat liver mitochondria. II. Methylene-tetrahydrofolate as the direct one carbon donor in the reaction of glycine synthesis. J. Biochem., 65: 71 (1969).

9. Sato, T., Kochi, H., Motokawa, Y., Kawasaki, H., and Kikuchi, G.: Glycine metabolism by rat liver mitochondria. 1. Synthesis of two molecules of glycine from one molecule each of serine, bicarbonate and ammonia. J. Biochem., 65: 63 (1969).

10. Sato, T., Kochi, H., Sato, N., and Kikuchi, G.: Glycine metabolism by rat liver mitochondria. III. The glycine cleavage and the exchange of carboxyl carbon of glycine with bicarbonate. J. Biochem., 65: 77 (1969).

11. Rosenberg, L. E., Lilljeqvist, A., and Hsia, Y. E.: Methylmalonic aciduria: An inborn error leading to metabolic acidosis, long-chain ketonuria and intermittent hyperglycinemia. New Engl. J. Med., 278: 1319 (1968).

12. Tada, K., Narisawa, K., Yoshida, T., Konno, T., Yokoyama, Y, Nakagawa, H., Tanno, K., Mochizuki, K., Arakawa, T., and Kikuchi, G.: Hyperglycinemia: A defect in glycine cleavage reaction. Tohoku J. Exp. Med., 98: 289 (1969).

13. Wada, Y., Tada, K., Takada, G., Omura, K., Yoshida, T., Kuniya, T., Aoyama, T., Hakui, T., and Harada, S.: Hyperglycinemia associated with hyperammonemia: In vitro glycine cleavage in liver. Pediat. Res., 6: 622 (1972).

14. Requests for reprints should be addressed to: K. Tada, M.D., Department of Pediatrics, Osaka City University Medical School, Abeno-ku, Osaka, Japan.

15. Accepted for publication March 13, 1974. 